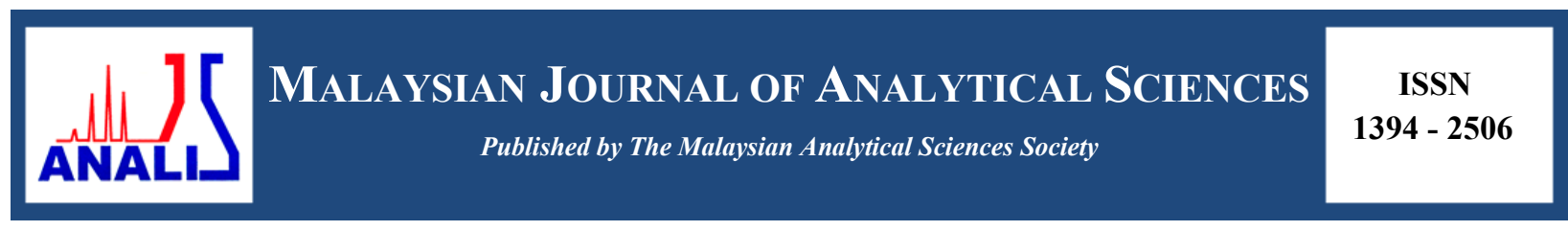

\title{
SYNTHESIS, STRUCTURAL, CHEMICAL PROPERTIES, AND ANTI- BACTERIAL SCREENING OF Sm(III) THIOSEMICARBAZONE COMPLEXES
}

\author{
(Sintesis, Struktur, Sifat-Sifat Kimia, dan Penyaringan Antibakteria bagi Kompleks \\ Sm(III) Tiosemikarbazon) \\ Nur Nadia Dzulkifli ${ }^{1}{ }^{2 *}$, Yang Farina ${ }^{1}$, Bohari M.Yamin ${ }^{1}$, Nazlina Ibrahim ${ }^{3}$ \\ ${ }^{I}$ School of Chemical Science and Food Technology, Faculty of Science and Technology \\ Universiti Kebangsaan Malaysia, 43600 UKM Bangi, Selangor, Malaysia \\ ${ }^{2}$ Department of Chemistry, Faculty of Applied Sciences, \\ Universiti Teknologi MARA, 72000 Kuala Pilah, Negeri Sembilan, Malaysia \\ ${ }^{3}$ School of Biosciences and Biotechnology, Faculty of Science and Technology \\ Universiti Kebangsaan Malaysia, 43600 UKM Bangi, Selangor, Malaysia \\ *Corresponding author: nurnadia@ns.uitm.edu.my
}

Received: 16 August 2016; Accepted: 12 March 2017

\begin{abstract}
Rare earth complexes can exhibit higher coordination numbers while rare earth metals have the ability to form a multitude of geometries with organic ligands. The ligands, $\left[\mathrm{Sm}(\mathrm{III})(4 \mathrm{Acpy} 4 \mathrm{MTSC})_{2}\left(4 \mathrm{H}_{2} \mathrm{O}\right) \mathrm{Cl}\right] \mathrm{Cl}_{2}$ and $\left[\mathrm{Sm}(\mathrm{III})(4 \mathrm{Acpy} 4 \mathrm{ETSC})\left(5 \mathrm{H}_{2} \mathrm{O}\right) \mathrm{Cl}_{2}\right] \mathrm{Cl}$ [4Acpy4MTSC = 4-acetylpyridine 4-methyl-3-thiosemicarbazone; 4Acpy4ETSC = 4-acetylpyridine 4-ethyl-3thiosemicarbazone] have been synthesised by condensation method. The compounds were structurally characterised by elemental analysis (CHNS), molar conductivity, Fourier Transform Infrared (FT-IR), Nuclear Magnetic Resonance (NMR), UltravioletVisible (UV-Vis), and Thermo-Gravimetric Analysis (TGA). The elemental analysis for the compounds were in a good agreement with the theoretical values. The molar conductivity of the complexes showed electrolyte behaviour and confirmed the presence of counter ions in the structures. The proposed structures of the compounds have been confirmed by NMR, UV-Vis, and TGA. Based on the analysis, the ligands were coordinated to the metal ions through azomethine $\mathrm{N}$ and thione $\mathrm{S}$ thus, producing bidentate complexes. From the TGA, it is confirmed that a few water molecules have coordinated with metal ions. The $\mathrm{X}$-ray crystallographic structures for the 4Acpy4ETSC, the $\mathrm{C}=\mathrm{S}$ bond length is shorter than the single bond $\mathrm{C}$-S which is $1.82 \AA$. It shows that in the solid state, the ligand exists in the thione form. The 4Acpy4ETSC adopted a monoclinic system, $a=$ 10.5922(7), $b=8.9597(6), c=13.0407, \mathrm{Z}=4$. In vitro antibacterial tests showed that the complexes have an effective inhibitory effect compared to the ligands because the presence of chloride ions, $\mathrm{Cl}^{-}$which caused the complexes to be more acidic, can inhibit bacterial growth.
\end{abstract}

Keywords: thiosemicarbazone, samarium(III), antibacterial screening

\section{Abstrak}

Sebatian kompleks nadir bumi boleh wujud dengan nombor koordinatan yang lebih tinggi dan logam nadir bumi berkeupayaan membentuk pelbagai geometri dengan ligan organik. Sebatian ligan, [Sm(III) (4Acpy4MTSC $\left.)_{2}\left(4 \mathrm{H}_{2} \mathrm{O}\right) \mathrm{Cl}\right] \mathrm{Cl}_{2} \mathrm{dan}[\mathrm{Sm}(\mathrm{III})$ (4Acpy4ETSC) $\left(5 \mathrm{H}_{2} \mathrm{O}\right) \mathrm{Cl}_{2}$ ] Cl [4Acpy4MTSC = 4-asetilpiridin 4-metil-3-tiosemikarbazon; 4Acpy4ETSC = 4-asetilpiridin 4-etil3-tiosemikarbazon] telah disintesiskan melalui kaedah kondensasi. Kesemua struktur sebatian telah dicirikan dengan analisis unsur (CHNS), kekonduksian molar, spektoskopi Inframerah Transformasi Fourier (FTIR), Resonans Magnet Nukleus (NMR), Ultralembayung-Sinar Nampak (UV-Vis), dan analisis termogravimetrik (TGA). Data analisis unsur bagi semua sebatian adalah hampir sama dengan nilai-nilai teori. Kekonduksian molar bagi sebatian kompleks menunjukkan sifat elektrolit dan 


\section{Nur Nadia et al: SYNTHESIS, STRUCTURAL, CHEMICAL PROPERTIES, AND ANTI-BACTERIAL SCREENING OF Sm(III) THIOSEMICARBAZONE COMPLEXES}

membuktikan kehadiran ion pembilang dalam struktur sebatian. Struktur jangkaan bagi sebatian telah dibuktikan dengan NMR, UV-Vis, dan TGA. Berdasarkan kepada analisis, ligan berkoordinat dengan ion logam melalui $\mathrm{N}$ azometina dan $\mathrm{S}$ tion dengan menghasilkan sebatian kompleks bersifat bidentat. Analisis TGA membuktikan kehadiran beberapa molekul air yang berkoordinat dengan ion logam. Struktur kristalografi sinar-X bagi 4Acpy4ETSC, panjang ikatan $C=S$ adalah lebih pendek daripada ikatan tunggal C-S iaitu $1.82 \AA$. Ini menunjukkan bahawa dalam keadaan pepejal, ligan wujud dalam bentuk tion. 4Acpy4ETSC menghablur dalam sistem monoklinik, $a=10.5922(7), b=8.9597(6), c=13.0407, \mathrm{Z}=4$. Ujian antibakteria invitro ke atas sebatian kompleks mempamerkan kesan perencatan yang lebih tinggi berbanding dengan ligan kerana kehadiran ion klorida, Cl- yang menyebabkan kompleks bersifat asid, boleh menghalang pertumbuhan bakteria.

Kata kunci: tiosemikarbazon, samarium(III), penyaringan antibakteria

\section{Introduction}

The study of thiosemicarbazone and their complex properties have favoured diverse researches that are related to the biological purposes [1-3]. Previous studies have reported that varied substitutions at the thioamide $\mathrm{N}$ atom have a powerful effect on the biological efficiency of the compounds [4]. The restructuring of the thiosemicarbazone framework is intended to get new compounds that will enhance their biological activity and be more reactive as an antibacterial agent [5]. 4-acetylpyridine complexes have the ability to inhibit bacteria cell growth where the activity greatly depends on the nature of the $N$-heterocyclic ring [6]. According to a study conducted by Rosu et al. [7], thiosemicarbazones do not show any bacterial inhibitor properties compared to their complexes against some microorganisms. This is due to chelation between thiosemicarbazones with metal ions that will reduce the metal ion polarity because of the shared positive charge between the donor atoms and metal ions. Moreover, the dispersion of the electrons in the rings may also influence the reactivity of thiosemicarbazones as an antibacterial agent. Thiosemicarbazones consist of $\mathrm{C}=\mathrm{N}$ and $\mathrm{C}=\mathrm{S}$ moieties which show favourable coordination towards metal ions [8]. Thiosemicarbazones consist of soft donor atoms; imine $\mathrm{N}$ and thiolate $\mathrm{S}$ where they act as $\delta$-donor and $\pi$-acceptor atoms that can stabilise the oxidation state of metal ions [9]. Thiosemicarbazone commonly reacts with the transition and lanthanide metals to form stable complexes through amine $\mathrm{N}$ and thiocarbonyl or thiolate $\mathrm{S}$ atoms in which have a few bonding modes such as monodentate, bidentate, and polydentate [10].

In this study, the ligands and Sm(III) complexes were synthesised and characterised by an elemental analysis, molar conductivity, UV-Visible, FT-IR, TGA, NMR and single crystal X-ray diffraction technique. In addition, the antibacterial activity of the compounds were investigated.

\section{Materials and Methods}

All reagents and reactants are of analytical grade and were used as received without further purification. The melting points of the synthesised compound were determined using the Electrothermal IA 9100. The elemental analysis was performed on the CHNS/O Model Fision EA 1180 and Thermo Finnigan Flash EA 1112 Series. 13C and 1H NMR spectra were recorded on a $600 \mathrm{MHz}$ FT-NMR Cryoprobe using DMSO-d 6 as solvent and tetramethylsilane as the internal reference. Chemical shifts were recorded in parts per million $(\delta)$. Infrared spectra of the ligands were recorded as $\mathrm{KBr}$ discs on FTIR Perkin Elmer model GX spectrophotometer in the $4000-400 \mathrm{~cm}^{-1}$ range. The thermogravimetric analysis (TGA) of the complexes was recorded on Mettler Toledo model TGA.SDTA 851e. The electronic absorption spectra were recorded on a Shimadzu UV-1650 PC and measured in the range of 200-800 nm in DMF. The molar conductivity was measured with DMF at room temperature using SI Analytic Lab 970 conductivity meter at the concentration of $1 \times 10^{-3} \mathrm{M}$.

The determination of the crystal structures of the ligand was carried out on a Bruker Smart APEX CCD area detector diffractometer equipped with graphite mono-chromatised Mo-K $\alpha(\lambda=0.71073 \AA)$ [11]. All data collection was carried out at 296K. Data collection: SMART [12]; cell refinement: SAINT [13]; data reduction: SAINT; program(s) used to solve structure: SHELXTL [14]; program(s) used to refine structure: SHELXTL [14] molecular graphics: SHELXTL [14]; software used to prepare material for publication: SHELXTL and PLATON [15]. Crystallographic data for the compounds Is2MTSC have been deposited with the Cambridge Crystallographic Data Centre, CCDC reference numbers (1007736). This information may be obtained free of charge from The Director, CCDC, 12 Union Road, Cambridge, CB2 1EZ, UK. 


\section{Synthesis of 4Acpy4MTSC and 4Acpy4ETSC}

4Acpy4MTSC: A methanolic solution $(10 \mathrm{~mL})$ of 4-acetylpyridine $(0.121 \mathrm{~g}, 10 \mathrm{mmol})$ was added to a methanolic solution $(10 \mathrm{~mL})$ of 4-methyl-3-thiosemicarbazide $(0.105 \mathrm{~g}, 10 \mathrm{mmol})$ followed by the addition of a few drops of acetic acid. The solution was heated under reflux for 2 hours, filtered and left to dry at room temperature to get the white precipitate which formed after 2 weeks. The 4Acpy4ETSC was synthesised following the same method as 4Acpy4MTSC. Colourless crystals suited for X-ray Crystallography were obtained from methanol by slow evaporation at room temperature after a few weeks. The purity of ligands was checked by TLC and verified by elemental analysis.

\section{Synthesis of Sm(III) complexes}

[Sm(III)(4Acpy4MTSC) $\left.)_{2}\left(4 \mathrm{H}_{2} \mathrm{O}\right)(\mathrm{Cl})\right] \mathrm{Cl}_{2}$ : A methanolic solution $(30 \mathrm{~mL})$ of 4-acetylpyridine 4-methyl-3thiosemicarbazone $(0.625 \mathrm{~g}, 3 \mathrm{mmol})$ was added dropwise into a methanolic solution $(5 \mathrm{~mL})$ of $\mathrm{Sm}$ (III) chloride hexahydrate $(0.364 \mathrm{~g}, 1 \mathrm{mmol})$. The solution was heated under reflux for 3 hours. The yellow precipitate was filtered, rinsed with hot methanol, and dried in the desiccator. The $\left[\mathrm{Sm}(\mathrm{III})(4 \mathrm{Acpy} 4 \mathrm{ETSC})_{2}\left(\mathrm{SH}_{2} \mathrm{O}\right)\left(\mathrm{Cl}_{2}\right)\right] \mathrm{Cl}$ was synthesised following the same method as $\left[\mathrm{Sm}(\mathrm{III})(4 \mathrm{Acpy} 4 \mathrm{MTSC})_{2}\left(4 \mathrm{H}_{2} \mathrm{O}\right)(\mathrm{Cl})\right] \mathrm{Cl}_{2}$. Their reactions were difficult to be confirmed by the TLC method because of their insolubility in a few organic solvents.

\section{Antibacterial screening}

Antibacterial activity of the synthesised compounds was tested against Gram-positive bacteria with different species by convenient, low cost, and ease of use method which was disc diffusion. The types of bacteria used for antibacterial screening are as follows: i. Bacillus subtilis (B. subtilis), ii. Staphylococcus epidermidis (S.epidermidis), iii. Staphylococcus auerus (S. aureus), iv. Bacillus thuringiensis (B. thuringiensis), and v. Methicillin-resistant Staphylococcus aureus (MRSA).

\section{Chemical properties}

\section{Results and Discussion}

The results of the elemental analysis of the compounds are shown in Table 1. The molar conductivity for the complexes was measured in DMF $\left(10^{-3} \mathrm{M}\right)$ at room temperature. The molar conductance for [Sm(III) (4Acpy4MTSC) $\left.{ }_{2}\left(4 \mathrm{H}_{2} \mathrm{O}\right) \mathrm{Cl}\right] \mathrm{Cl}_{2}$ showed that the complex was $1: 2$ electrolyte, while [Sm(III) (4Acpy4ETSC) $\left.\left(5 \mathrm{H}_{2} \mathrm{O}\right) \mathrm{Cl}_{2}\right] \mathrm{Cl}$ was 1:1 electrolyte behaviour. It shows that the complexes have anions, $\mathrm{Cl}^{-}$outside the metal coordination sphere [16]. The proposed structures for the Sm(III) complexes are shown in Figure 1.

Table 1. Chemical properties of the compounds

\begin{tabular}{|c|c|c|c|c|c|c|}
\hline \multirow[t]{2}{*}{ Compounds } & \multirow[t]{2}{*}{ Colour } & \multirow{2}{*}{$\begin{array}{c}\text { Yield } \\
(\%)\end{array}$} & \multicolumn{4}{|c|}{$\begin{array}{c}\text { Composition Percentage, } \% \\
\text { (Calculated) }\end{array}$} \\
\hline & & & $\mathbf{C}$ & $\mathbf{H}$ & $\mathbf{N}$ & $\mathbf{S}$ \\
\hline 4Acpy4MTSC & White precipitate & 90 & $\begin{array}{c}51.11 \\
(51.90)\end{array}$ & $\begin{array}{c}5.52 \\
(5.81)\end{array}$ & $\begin{array}{l}25.48 \\
(26.90)\end{array}$ & $\begin{array}{c}14.28 \\
(15.39)\end{array}$ \\
\hline 4Acpy4ETSC & Colourless crystal & 92 & $\begin{array}{c}53.64 \\
(54.03)\end{array}$ & $\begin{array}{c}5.82 \\
(6.35)\end{array}$ & $\begin{array}{l}25.08 \\
(25.20)\end{array}$ & $\begin{array}{r}14.08 \\
(14.42)\end{array}$ \\
\hline$\left[\mathrm{Sm}(\mathrm{III})(4 \mathrm{Acpy} 4 \mathrm{MTSC})_{2}\left(4 \mathrm{H}_{2} \mathrm{O}\right)(\mathrm{Cl})\right] \mathrm{Cl}_{2}$ & Yellow precipitate & 83 & $\begin{array}{c}28.89 \\
(29.01)\end{array}$ & $\begin{array}{c}4.11 \\
(4.33)\end{array}$ & $\begin{array}{c}14.78 \\
(15.03)\end{array}$ & $\begin{array}{c}7.69 \\
(8.60)\end{array}$ \\
\hline$\left[\mathrm{Sm}(\mathrm{III})(4 \mathrm{Acpy} 4 \mathrm{ETSC})_{2}\left(5 \mathrm{H}_{2} \mathrm{O}\right)\left(\mathrm{Cl}_{2}\right)\right] \mathrm{Cl}$ & Yellow precipitate & 89 & $\begin{array}{c}21.82 \\
(22.62)\end{array}$ & $\begin{array}{c}4.98 \\
(4.66)\end{array}$ & $\begin{array}{l}10.01 \\
(9.59)\end{array}$ & $\begin{array}{c}5.27 \\
(5.49)\end{array}$ \\
\hline
\end{tabular}




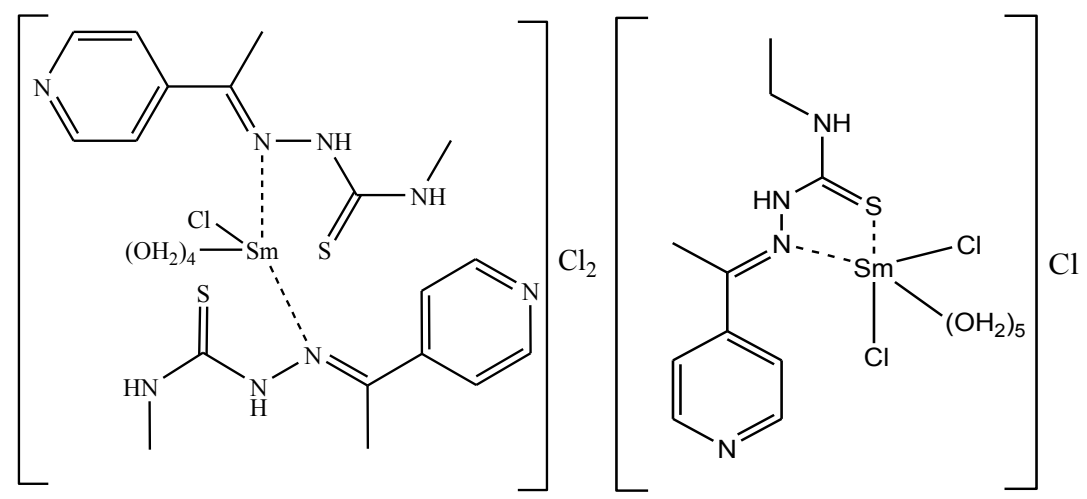

Figure 1. The proposed structures of the Sm(III) complexes

\section{Infrared spectra}

The infrared spectra of complexes and ligands were reported in the range of $200-400$ and $400-4000 \mathrm{~cm}^{-1}$, respectively, as shown in Figure 2. The comparison of stretching bands between the compounds is important to certify the coordination that occurs in the formation of complexes. The stretching band of $v(\mathrm{~S}-\mathrm{H})$ in the range of 2600 to $2800 \mathrm{~cm}^{-1}$ implies that the ligands exist as tautomeric thione in the solid state [17, 18]. In addition, the presence of an amine group stretching band, $v(\mathrm{NH})$ in the range of $3150-3320 \mathrm{~cm}^{-1}$ for the spectra of ligands also proved that ligands remain as thione tautomeric when in the solid state [19]. The absence of thiol stretching band, $v(\mathrm{~S}-\mathrm{H})$ in the range $2600-2800 \mathrm{~cm}^{-1}$ and the existence of thiocarbonyl, $v(\mathrm{C}=\mathrm{S})$ stretching band imply that the ligands will be presented as thione tautomeric in the solid state. Besides that, the existence of an amine, $v(\mathrm{~N}-\mathrm{H})$ stretching band at $3193 \mathrm{~cm}^{-1}$ (4Acpy4MTSC) and $3151 \mathrm{~cm}^{-1}$ (4Acpy4ETSC) also verified that the ligands remain as thione tautomers in the solid state. The stretching band $v(\mathrm{C}=\mathrm{N})$ for the ligands exists at $1589 \mathrm{~cm}^{-1}$. While for the complexes, the stretching band of $v(\mathrm{C}=\mathrm{N})$ was shifted to higher wavenumber due to the coordination between the ligands to the metal ion through donor atoms, $\mathrm{N}$-imine [20]. The stretching bands $v(\mathrm{C}=\mathrm{S})$ for the ligand 4Acpy4MTSC and 4Acpy4ETSC showed up at 822 and $826 \mathrm{~cm}^{-1}$, respectively. The stretching band was shifted to lower wavenumber, $821 \mathrm{~cm}^{-1}$ for $\left[\mathrm{Sm}(\mathrm{III})\right.$ (4Acpy4ETSC) $\left.\left(5 \mathrm{H}_{2} \mathrm{O}\right) \mathrm{Cl}_{2}\right] \mathrm{Cl}$ due to the coordination that occurred between thiocarbonyl sulfur with a metal ion. While the stretching band, $v(\mathrm{C}=\mathrm{S})$ in $[\mathrm{Sm}(\mathrm{III})$ (4Acpy4MTSC) $\left.\left(5 \mathrm{H}_{2} \mathrm{O}\right) \mathrm{Cl}_{2}\right] \mathrm{Cl}$ was not shifted as it proved that no coordination occurred through $\mathrm{S}$ [21]. The coordination between azomethine, $\mathrm{N}$ and thiocarbonyl sulfur to metal ion was verified with the presence of stretching bands, $v(\mathrm{Sm}-\mathrm{N})$ in the range $420-442 \mathrm{~cm}^{-1}$ [22] and $v(\mathrm{Sm}-\mathrm{S})$ at $353 \mathrm{~cm}^{-1}$ [23]. In addition, the existence of two new stretching bands, $v(\mathrm{Sm}-\mathrm{Cl})$ and $v(\mathrm{Sm}-\mathrm{O})$ also showed that chloride ions and water molecules are also coordinated to metal ion to form high stability complexes.

\section{Thermogravimetric analysis}

The thermogravimetric analysis (TGA) $\left(20-800{ }^{\circ} \mathrm{C}\right)$ was recorded for the prepared ligands and complexes to distinguish between the coordinated and hydrate water molecules and study the thermal stability of the compounds. In order to evaluate the thermal stability of the prepared Sm(III) complexes, the TGA plot of the ligands was compared with $\mathrm{Sm}$ (III) complexes. The decomposition of the prepared complexes was not fully completed compared to the ligands as the instrument constraints only allow combustion of up to $800{ }^{\circ} \mathrm{C}$. Referring to Figure 3 , these complexes will be fully decomposed above $800{ }^{\circ} \mathrm{C}$ to produce $\mathrm{MS}_{2}$ or $\mathrm{MO}_{2}$ as a residue. Moreover, water molecules evaporate at less than $100{ }^{\circ} \mathrm{C}$, which is likely that the complexes are not completely dry. Meanwhile, the temperatures between $100-300{ }^{\circ} \mathrm{C}$ are referred to the loss of water molecules coordinated with $\mathrm{Sm}(\mathrm{III})$ ion which can be supported by the proposed structures [24]. The complexes have a higher thermal stability than the ligands because the thermal stability is enhanced when the complexation occurred. Besides that, the decomposition of chloride, $\mathrm{Cl}^{-}$and nitrate ions, $\mathrm{NO}_{3}{ }^{-}$also occurred in this temperature range [25]. 


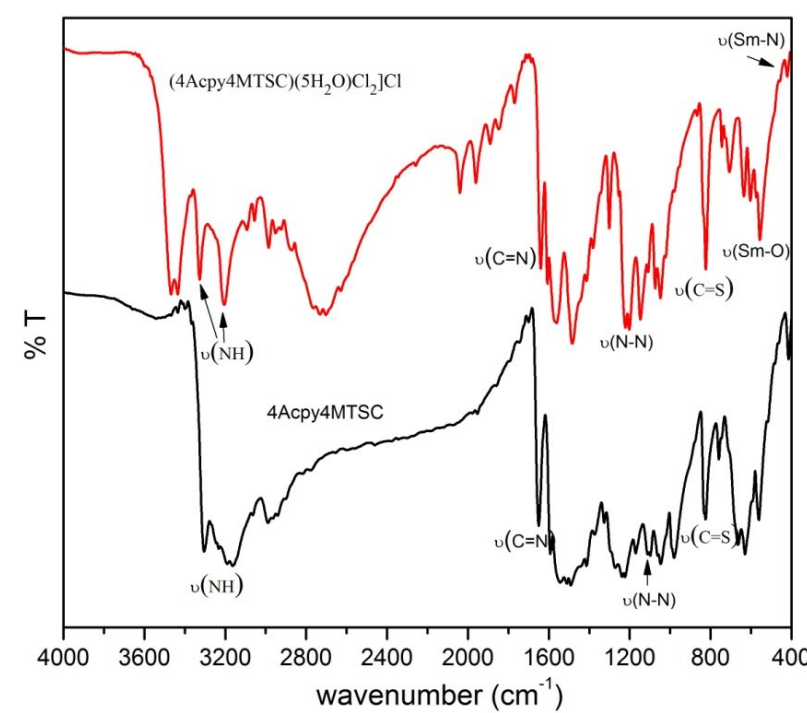

(a)

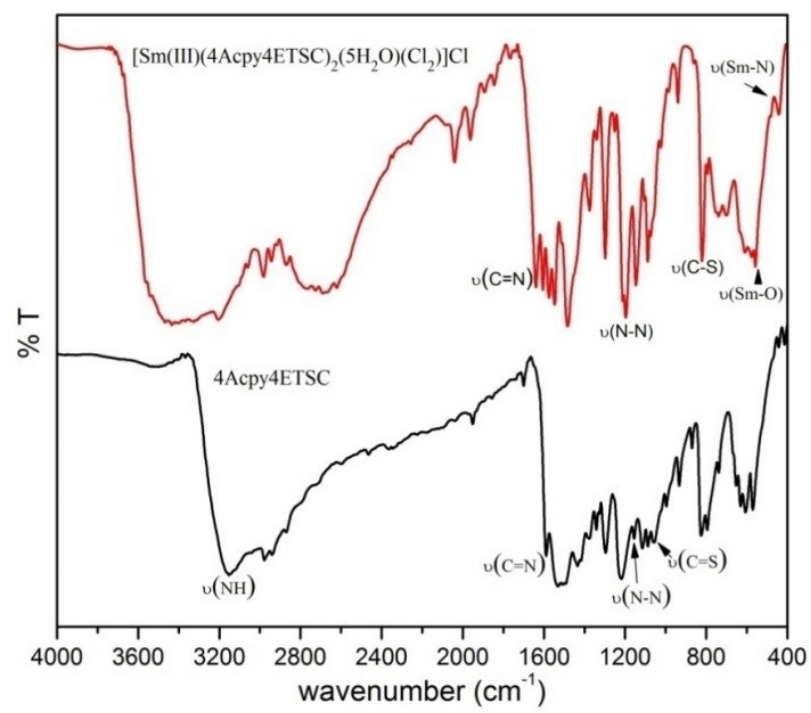

(b)

Figure 2. Infrared spectral of (a) 4Acpy4MTSC, (b) 4Acpy4ETSC and Sm(III) complexes

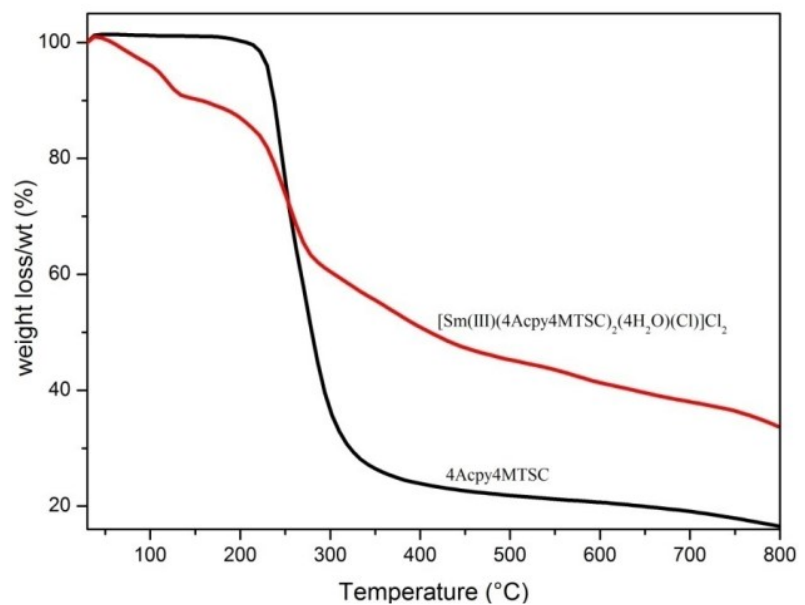

(a)

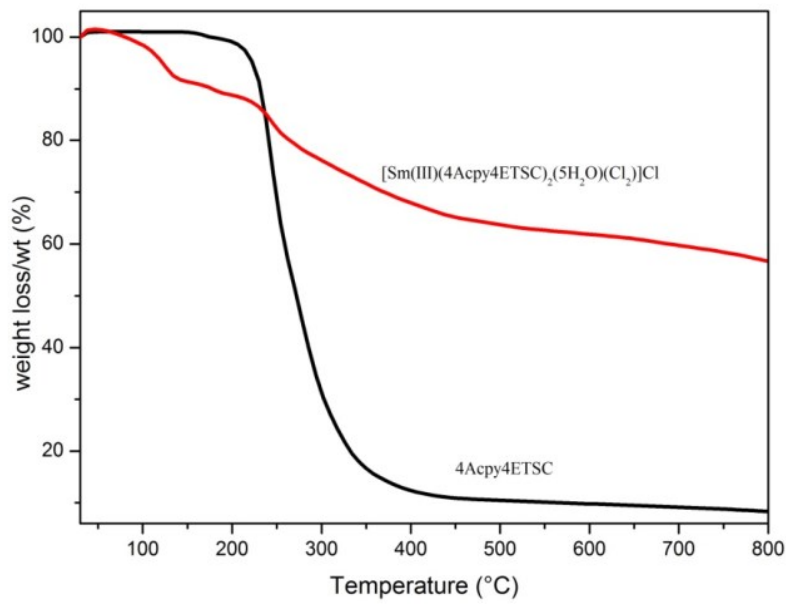

(b)

Figure 3. Thermogram of (a) 4Acpy4MTSC, (b) 4Acpy4ETSC and Sm(III) complexes

\section{Absorption spectra}

The absorption spectra of the ligands and Sm(III) complexes were determined in DMSO solution $\left(c=1 \times 10^{-5} \mathrm{M}\right)$. The spectra of 4Acpy4MTSC and 4Acpy4ETSC displayed almost similar diagrams in the range of $200-400 \mathrm{~nm}$ regions. The absorption spectra for 4Acpy4MTSC were composed of three intense absorption peaks at 205.50, 237.50, and $315.50 \mathrm{~nm}$ which appointed to $\mathrm{n} \rightarrow \sigma^{*}, \pi \rightarrow \pi^{*}$, and $\mathrm{n} \rightarrow \pi^{*}$, while 4Acpy4ETSC was composed of four intense bands at $211.00\left(n \rightarrow \sigma^{*}\right), 243.50,253.00\left(\pi \rightarrow \pi^{*}\right)$, and $320.50\left(n \rightarrow \pi^{*}\right)$. The electronic transitions refer to the presence of azomethine, thioamide, and benzene rings. In addition, according to Tulay et al. [26], electronic 
transition, $\pi \rightarrow \pi *$ refers to the transition of electrons in imine, $\mathrm{C}=\mathrm{N}$. The formation of the $\mathrm{Sm}$ (III) complexes led to the change in the absorption region $(200-400 \mathrm{~nm})$. This is probably because of the conjugation effect caused by the deprotonation of the ligands upon coordination. The spectra of $\left[\mathrm{Sm}(\mathrm{III})(4 \mathrm{Acpy} 4 \mathrm{MTSC})_{2}\left(4 \mathrm{H}_{2} \mathrm{O}\right)(\mathrm{Cl}) \mathrm{Cl}_{2}\right.$ were composed of three intense absorption peaks at 206.00, 233.00, and $315.50 \mathrm{~nm}$ which appointed to $\mathrm{n} \rightarrow \sigma^{*}, \pi \rightarrow \pi^{*}$, and $\mathrm{n} \rightarrow \pi^{*}$, while $\left[\mathrm{Sm}(\mathrm{III})(4 \mathrm{Acpy} 4 \mathrm{ETSC})_{2}\left(5 \mathrm{H}_{2} \mathrm{O}\right)\left(\mathrm{Cl}_{2}\right)\right] \mathrm{Cl}$ was composed of three intense absorption peaks at 203.50, 235.00, and $315.50 \mathrm{~nm}$ which appointed to $\mathrm{n} \rightarrow \sigma^{*}, \pi \rightarrow \pi^{*}$, and $\mathrm{n} \rightarrow \pi^{*}$. The slight shifting of absorption peaks proves that the coordination occurred through azomethine $\mathrm{N}$ and thiocarbonyl $\mathrm{S}$ [27]. No absorption peak for $f-f$ transition appeared in the visible region presumably due to the very weak transition. Besides that, Taha et al. [28] reported that $\mathrm{Sm}$ (III) ion is not involved in the absorption of complexes as the $f-f$ transition is a Laporte forbidden transition, which is assumed to be too weak to appear in the visible range with low molar absorption coefficient.

Nuclear Magnetic Resonance analysis

The results of the Nuclear Magnetic Resonance of the ligands are shown in Table 2.

Table 2. NMR spectra data of the ligands

\begin{tabular}{llclc}
\hline Compounds & Type of Protons & $\begin{array}{c}\text { Chemical Shift } \boldsymbol{\delta} \\
(\mathbf{p p m})\end{array}$ & Type of Carbons & $\begin{array}{c}\text { Chemical Shift } \boldsymbol{\delta} \\
(\mathbf{p p m})\end{array}$ \\
\hline \multirow{2}{*}{ 4Acpy4MTSC } & $\mathrm{N}-\mathrm{CH}_{3}(\mathrm{~d})$ & $3.04-3.05$ & $-\mathrm{CH}_{3}$ & 31.65 \\
& $\mathrm{~N}(1) \mathrm{H}(\mathrm{s})$ & 2.49 & $\mathrm{C}=\mathrm{S}$ & 179.31 \\
& $\mathrm{~N}(2) \mathrm{H}(\mathrm{s})$ & 10.39 & $\mathrm{C}=\mathrm{N}$ & 150.22 \\
& $\mathrm{CH}_{3} \mathrm{C}=\mathrm{N}(\mathrm{s})$ & 2.28 & $\mathrm{CH}_{3} \mathrm{C}=\mathrm{N}$ & 13.80 \\
& Aromatic (m) & $7.87-8.59$ & Aromatic & $121.09,145.21$ \\
\hline 4Acpy4ETSC & $-\mathrm{CH}_{3}(\mathrm{t})$ & $1.13-1.17$ & $-\mathrm{CH}_{3}$ & 14.85 \\
& $\mathrm{~N}-\mathrm{CH}_{2}(\mathrm{~m})$ & $3.59-3.66$ & $-\mathrm{CH}_{2}$ & 39.05 \\
& $\mathrm{~N}(2) \mathrm{H}(\mathrm{s})$ & 10.30 & $\mathrm{C}=\mathrm{S}$ & 178.27 \\
& $\mathrm{~N}(1) \mathrm{H}(\mathrm{t})$ & $8.63-8.66$ & $\mathrm{C}=\mathrm{N}$ & 150.23 \\
& $\mathrm{CH}$ & 2.28 & $\mathrm{CH}$ & $\mathrm{N}(\mathrm{s})$ \\
& $\mathrm{Aromatic}(\mathrm{m})$ & $7.86-8.59$ & Aromatic & $121.09,145.20,145.30$ \\
\hline
\end{tabular}

Based on Table 2, the chemical shift for $\mathrm{N}(2) \mathrm{H}$ appeared at downfield, 10.39 and $10.30 \mathrm{ppm}$ for 4Acpy4MTSC and 4Acpy4ETSC, respectively, with singlet multiplicity. For 4Acpy4MTSC, the spin multiplicity of N(1)H is a singlet different from the theory, as it should be generating quartet. This is because the presence of $\mathrm{D}_{2} \mathrm{O}$ has caused nitrogen protons to exchange with deuterium, then indirectly; the resonance disappears and exists as a singlet. Besides that, from the NMR data, it was revealed that the ligands exist as thione form caused by the absence of S-H protons and existence of $\mathrm{C}=\mathrm{S}$ and $\mathrm{C}=\mathrm{N}$ bonds. The protons of the phenyl group also appeared at downfield due to the presence of magnetic anisotropy and resonance effect. The chemical shifts for DMSO deuterated appeared in the range of $2-5 \mathrm{ppm}$. The NMR data proved the proposed structures of ligands as recommended. The complexes have paramagnetic properties and are not suitable for NMR analysis.

\section{X-ray structure determination}

The molecular structure of the ligand along with the atomic numbering scheme is shown in Figure 4 . The crystal data and structure refinement and H-bonding parameters of the ligand are shown in Tables 3 and 4, respectively. 


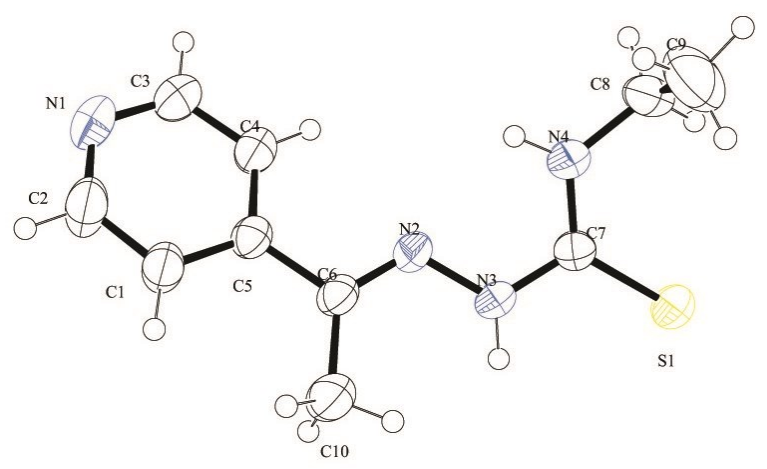

Figure 4. The molecular structure of (4Acpy4ETSC) with the atom labelling scheme. Displacement ellipsoids are drawn at the $50 \%$ probability level

Table 3. Crystal data and structure refinement for the ligand, 4Acpy4ETSC

\begin{tabular}{ll}
\hline & 4Acpy4ETSC \\
\hline Chemical formula & $\mathrm{C}_{10} \mathrm{H}_{14} \mathrm{~N}_{4} \mathrm{~S}$ \\
Molar mass $(\mathrm{g})$ & 222.31 \\
Crystal system & Monoclinic \\
Space group & $P 2_{1} / \mathrm{c}$ \\
$a(\AA)$ & $10.5922(7)$ \\
$b(\AA)$ & $8.9597(6)$ \\
$c(\AA)$ & 13.0407 \\
$\alpha\left(^{\circ}\right)$ & 90 \\
$\beta\left(^{\circ}\right)$ & $106.025(2)$ \\
$\gamma\left(^{\circ}\right)$ & 90 \\
$V\left(\AA^{3}\right)$ & $1189.51(14)$ \\
Mo K $\alpha(\AA)$ & 0.71073 \\
$Z$ & 4 \\
D/Mgm & \\
$F(000)$ & 1.241 \\
Colour & 472 \\
Shape & Colourless \\
Crystal size (mm) & Block \\
Temperature $(K)$ & $0.35,0.60,0.33$ \\
Range $\theta\left(^{\circ}\right)$ & $302(2)$ \\
Goodness of fit on $F^{2}$ & $3.029-28.368$ \\
Indexes R final, $I>2 \sigma(I)$ & 1.048 \\
Indexes $R($ All data $)$ & 0.0619 \\
\hline & 0.1001 \\
\hline
\end{tabular}




\section{Nur Nadia et al: SYNTHESIS, STRUCTURAL, CHEMICAL PROPERTIES, AND ANTI-BACTERIAL SCREENING OF Sm(III) THIOSEMICARBAZONE COMPLEXES}

Table 4. Hydrogen bonding parameters for 4Acpy4ETSC

\begin{tabular}{|c|c|c|c|c|c|c|}
\hline & D---H...A & Type & D-H (Å) & H...A ( $(\AA)$ & D...A ( $(\AA)$ & D-H...A( $\left(^{\circ}\right)$ \\
\hline & 4Acpy4ETSC & & & & & \\
\hline $\mathrm{i}$ & $\mathrm{N}(3)---\mathrm{H}(3 \mathrm{~A}) \ldots \mathrm{S}(1)$ & Inter & 0.88 & 2.58 & 3.4523 & 173 \\
\hline ii & $\mathrm{N}(4)---\mathrm{H}(4 \mathrm{~A}) \ldots \mathrm{N}(2)$ & Intra & 0.87 & 2.21 & 2.6111 & 108 \\
\hline iii & $\mathrm{N}(4)---\mathrm{H}(4 \mathrm{~A}) \ldots \mathrm{N}(1)$ & Inter & 0.87 & 2.23 & 2.9945 & 146 \\
\hline iv & $\mathrm{C}(8)---\mathrm{H}(8 \mathrm{~B}) \ldots \mathrm{S}(1)$ & Intra & 0.97 & 2.72 & 3.1041 & 104 \\
\hline $\mathrm{v}$ & $\mathrm{C}(10)---\mathrm{H}(10 \mathrm{C}) \ldots \mathrm{N}(3)$ & Intra & 0.96 & 2.45 & 2.8210 & 103 \\
\hline
\end{tabular}

Symmetry codes: i. 1-x,-y,-z, and ii. -x,1/2+y,1/2-z

For 4Acpy4ETSC, pyridine ring N1/C1/C2/C3/C4/C5, as shown in Figure 4, is planar with a maximum deviation of $0.014 \AA$ for the $\mathrm{C} 5$ atom from the least square plane. Thiourea moiety, $\mathrm{S} 1 / \mathrm{N} 3 / \mathrm{N} 4 / \mathrm{C} 7$ is planar with a maximum deviation of atoms at $0.009 \AA \mathrm{C} 7$ from the least square plane. 4Acpy4ETSC ligand is connected with hydrogen bonds as listed in Table 2 to form 1D chain along the $b$ axis. Referring to Table 5, for azomethine moiety, $\mathrm{C}(6)-\mathrm{N}(2)$ and $\mathrm{S}(1)-\mathrm{C}(7)$ is a double bond in which the bond length varies with the theoretical value. This is due to the effect of conjugation and delocalisation of electron density in the molecule [29].

Table 5. Selected bond lengths and angles for 4Acpy4ETSC

\begin{tabular}{lclc}
\hline Bond & Bond Length $(\AA)$ & Bond & Bond Angles $\left.\mathbf{(}^{\boldsymbol{9}}\right)$ \\
\hline $\mathrm{S}(1)-\mathrm{C}(7)$ & 1.6803 & $\mathrm{C}(2)-\mathrm{N}(1)-\mathrm{C}(3)$ & 115.81 \\
$\mathrm{~N}(1)-\mathrm{C}(2)$ & 1.3262 & $\mathrm{C}(7)-\mathrm{N}(4)-\mathrm{C}(8)$ & 124.41 \\
$\mathrm{~N}(1)-\mathrm{C}(3)$ & 1.3281 & $\mathrm{~N}(1)-\mathrm{C}(3)-\mathrm{C}(4)$ & 124.34 \\
$\mathrm{~N}(2)-\mathrm{N}(3)$ & 1.3777 & $\mathrm{~S}(1)-\mathrm{C}(7)-\mathrm{N}(4)$ & 124.32 \\
$\mathrm{~N}(4)-\mathrm{C}(8)$ & 1.4566 & $\mathrm{~N}(3)-\mathrm{N}(2)-\mathrm{C}(6)$ & 119.30 \\
$\mathrm{~N}(4)-\mathrm{C}(7)$ & 1.3229 & $\mathrm{~N}(3)-\mathrm{C}(7)-\mathrm{N}(4)$ & 116.39 \\
$\mathrm{~N}(3)-\mathrm{C}(7)$ & 1.3596 & $\mathrm{~N}(2)-\mathrm{N}(3)-\mathrm{C}(7)$ & 118.39 \\
$\mathrm{~N}(2)-\mathrm{C}(6)$ & 1.2741 & $\mathrm{~N}(1)-\mathrm{C}(2)-\mathrm{C}(1)$ & 124.45 \\
& & $\mathrm{~N}(2)-\mathrm{C}(6)-\mathrm{C}(5)$ & 114.83 \\
& & $\mathrm{~S}(1)-\mathrm{C}(7)-\mathrm{N}(3)$ & 119.27 \\
& & $\mathrm{~N}(4)-\mathrm{C}(8)-\mathrm{C}(9)$ & 112.26 \\
\hline
\end{tabular}

\section{Antibacterial screening}

The synthesised compounds tested for their in vitro antibacterial activity against Gram-positive bacteria by disc diffusion method and their diameters of the zones inhibition are listed in Table 6. From the observation, it can be concluded that the complexes are more active as antibacterial agent compared to the ligands. This phenomenon is caused by the presence of chelation between metal ion with the ligands in which will lower the polarity of metal ion caused by the partial sharing between positively charged metal ions with the donor atoms, $\mathrm{N}$ and $\mathrm{O}$ [30]. This will increase the chelation lipophilic properties of the metal ion which will indirectly increase the penetration abilities of the complexes through the cell walls of microorganisms. Increasing the lipophilic properties of the complexes will inhibit the growth of bacteria [31]. In addition, when the metal ions or complexes were adsorbed onto the bacteria wall, they will indirectly inhibit the respiration cell and protein production process. Hence, this phenomenon will inhibit the growth of the bacteria. Besides that, the complexes showed that the inhibitory activities are more active compared to the ligands due to the presence of chloride ions, $\mathrm{Cl}^{-}$that are acting as electron withdrawing group 
which causes them to be more acidic. In addition, due to the high degree of solubility of these compounds in the solvent DMSO, they are easily absorbed into the cells of bacteria through the membrane [32].

Table 6. Antibacterial activity of ligands and Sm(III) complexes

\begin{tabular}{lccccc}
\hline \multirow{2}{*}{ Compounds } & B. Subtilis & S. Epidermidis & S. Aureus & B. Thuringiensis & MRSA \\
\cline { 2 - 6 } & \multicolumn{5}{c}{ Diameter of the Zones of Inhibition $(\mathbf{c m})$} \\
\hline 4Acpy4MTSC & 0.65 & 0.70 & 0.65 & 0.65 & 0.65 \\
4Acpy4ETSC & 0.65 & 0.70 & 0.60 & 0.65 & 0.70 \\
{$\left[\mathrm{Sm}(\mathrm{III})(4 \mathrm{Acpy} 4 \mathrm{MTSC})_{2}\left(4 \mathrm{H}_{2} \mathrm{O}\right)(\mathrm{Cl})\right] \mathrm{Cl}_{2}$} & 1.00 & 0.90 & 1.00 & 1.10 & 0.65 \\
{$\left[\mathrm{Sm}(\mathrm{III})(4 \mathrm{Acpy} 4 \mathrm{ETSC})_{2}\left(5 \mathrm{H}_{2} \mathrm{O}\right)\left(\mathrm{Cl}_{2}\right)\right] \mathrm{Cl}$} & 0.90 & 0.90 & 0.80 & 0.80 & 0.60 \\
\hline
\end{tabular}

\section{Conclusion}

Two ligands and complexes were successfully synthesised and the proposed structures were supported by the elemental analysis, infrared, UV-Vis, molar conductivity, TGA, and X-ray Crystallographic study. The ligands exist as thione form in the solid state, which were proven by the X-ray Crystallographic study. The complexes showed 1:2 and 1:1 electrolytic behaviour for 4Acpy4MTSC and 4Acpy4ETSC, respectively, with molecular formula of $\left[\mathrm{Sm}(\mathrm{III})(4 \mathrm{Acpy} 4 \mathrm{MTSC})_{2}\left(4 \mathrm{H}_{2} \mathrm{O}\right) \mathrm{Cl}\right] \mathrm{Cl}_{2}$ and $\left[\mathrm{Sm}(\mathrm{III})(4 \mathrm{Acpy} 4 \mathrm{ETSC})\left(5 \mathrm{H}_{2} \mathrm{O}\right) \mathrm{Cl}_{2}\right] \mathrm{Cl}$. From the infrared and UV-Vis spectra, it can be seen that the ligands are coordinated with $\mathrm{Sm}(\mathrm{III})$ through azomethine $\mathrm{N}$ and thiocarbonyl, $\mathrm{S}$ as recommended by the proposed structures. The existence of coordinated $\mathrm{H}_{2} \mathrm{O}$ molecules with $\mathrm{Sm}$ (III) was proven by TGA which supported the proposed structures. An antibacterial screening implies that the Sm(III) complexes exhibit higher antibacterial activity compared to the ligands. These performances are due to the presence of chloride ions, $\mathrm{Cl}^{-}$which caused the complexes to be more acidic and therefore, inhibit bacterial growth.

\section{Acknowledgement}

The authors would like to thank the Faculty of Science and Technology, Universiti Kebangsaan Malaysia and the Centre for Research and Instrumentation (CRIM) for the research facilities, provision of laboratory facilities, and technical assistance. This study is financially supported by the research grant from GUP-2012-022, FRGS/2/2013/ST01/UKM/01/2, Universiti Teknologi MARA (UiTM) and scholarship from MyBrain15.

\section{References}

1. Demoro, B., De, A. R. F. M., Marques, F., Matos, C. P., Otero, L., Costa, Pes, J., Santos, I., Rodriguez, A., Moreno, V., Lorenzo, J., Gambino, D. and Tomaz, A. I. (2013). Screening organometallic binuclear thiosemicarbazone ruthenium complexes as potential anti-tumour agents: cytotoxic activity and human serum albumin binding mechanism. Dalton Transactions, 42(19): 7131 - 7146.

2. Atalay, T. and Akgemci, E. G. (1998). Thermodynamic studies of some complexes of 2-benzoylpyridine 4phenyl-3-thiosemicarbazone. Turkish Journal of Chemistry, 22: 123 - 128.

3. Seda, S., Baybars, K., Fatma, K. and Sevgi, H. B. (2009). Theoretical and spectroscopic studies of 5-fluoroisatin-3-(N-benzylthiosemicarbazone) and its zinc(II) complex. Journal of Molecular Structure, 917: 63 - 70.

4. Bernhardt, P. V., Sharpe, P. C., Islam, M., Lovejoy, D. B., Kalinowski, D. S. and Richardson, D. R. (2008). Iron chelators of the dipyridylketone thiosemicarbazone class: precomplexation and transmetalation effects on anticancer activity. Journal of Medicinal Chemistry, 52(2): 407 - 415.

5. Nguyen, T. B. Y., Pham, C. T., Trieu, T. N., Abram, U. and Nguyen, H. H. (2015). Syntheses, structures and biological evaluation of some transition metal complexes with a tetradentate benzamidine/thiosemicarbazone ligand. Polyhedron, 96: 66 - 70.

6. Matesanz, A. I., Tapia, S. and Souza, P. (2016). First 3,5-diacetyl-1,2,4-triazol derived mono(thiosemicarbazone) and its palladium and platinum complexes: Synthesis, structure and biological properties. Inorganica Chimica Acta, 445: 62 - 69. 
Nur Nadia et al: SYNTHESIS, STRUCTURAL, CHEMICAL PROPERTIES, AND ANTI-BACTERIAL

SCREENING OF Sm(III) THIOSEMICARBAZONE COMPLEXES

7. Rosu, T., Pahontu, E., Pasculescu, S., Georgescu, R., Stanica, N., Curaj, A., Popescu, A. and Leabu, M. (2010). Synthesis, characterization antibacterial and antiproliferative activity of novel $\mathrm{Cu}(\mathrm{II})$ and $\mathrm{Pd}(\mathrm{II})$ complexes with 2-hydroxy-8-R-tricyclo[7.3.1.0. $\left.{ }^{2,7}\right]$ tridecane-13-one thiosemicarbazone. European Journal of Medicinal Chemistry, 45: 1627 - 1634.

8. Feng, L., Shi, W., Ma, J., Chen, Y., Kui, F., Hui. Y. and Xie, Z. (2016). A novel thiosemicarbazone Schiff base derivative with aggregation-induced emission enhancement characteristics and its application in $\mathrm{Hg}^{2+}$ detection. Sensors and Actuators B: Chemical, 237: 563 - 569.

9. Hosseini-Yazdi, S. A., Hosseinpour, S., Khandar, A. A., Kassel, W. S. and Piro, N. A. (2015). Copper(II) and nickel(II) complexes with two new bis(thiosemicarbazone) ligands: Synthesis, characterization, X-ray crystal structures and their electrochemistry behavior. Inorganica Chimica Acta, 427: 124 - 130.

10. Shahsavani, E., Khalaji, A. D., Feizi, N., Kucerakova, M. and Dusek, M. (2015). Synthesis, characterization, crystal structure and antibacterial activity of new sulfur-bridged dinuclear silver(I) thiosemicarbazone complex $\left[\mathrm{Ag}_{2}\left(\mathrm{PPh}_{3}\right)_{2}(\mu-\mathrm{S}-\mathrm{Brcatsc})_{2}\left(\mathrm{n}^{1}-\mathrm{S}-\mathrm{Brcatsc}\right)_{2}\right]\left(\mathrm{NO}_{3}\right)_{2}$. Inorganica Chimica Acta, 429: $61-66$.

11. Awang, N. W., Hasbullah, S. A., Yusoff, S. F. M. and Yamin, B. M. (2014). N-[Ethyl(2-hydroxyethyl)carbamothioyl]-3-fluorobenzamide. Acta Crystallographica Section E: Structure Reports Online, 70(5): 570.

12. Bruker (2009). SMART, SAINT and SADABS. Bruker AXS Inc., Madison, Wisconsin, USA.

13. Bruker (2008). APEX2, SAINT and SADABS. Bruker AXS Inc., Madison, WI.

14. Sheldrick, G. M. (2008). A short history of SHELX. Acta Crystallographica Section A: Foundations of Crystallography, 64(1), $112-122$.

15. Spek, A. L. (2009). Structure validation in chemical crystallography. Acta Crystallographica Section D: Biological Crystallography, 65(2): 148 - 155.

16. Seleem, H. S., Emara, A. A. and Shebl, M. (2005). The relationship between ligand structures and their Co(II) and $\mathrm{Ni}(\mathrm{II})$ complexes: Synthesis and characterization of novel dimeric $\mathrm{Co}(\mathrm{II}) / \mathrm{Co}(\mathrm{III})$ complexes of bis(thiosemicarbazone). Journal of Coordination Chemistry, 58(12): 1003 - 1019.

17. Rai, D. K. and Singh, A. (2013). Synthesis, characterization and catalytic activity of transition metal complexes with thiosemicarbazone core ligand. Indian Journal of Science Research, 4(2): 129 - 133.

18. Liu, Y. Y., Ma, J. F. and Yang, J. (2007). Syntheses and structures of Zn(II) and Ni(II) complexes of 4-N(acetylacetone amine)acetophenonehiosemicarbazone. Journal Coordination of Chemistry, 60(14): 1579 1586.

19. Chatterjee, M. and Ghosh, S. (1998). Vanadium(III) complexes of salicylaldehyde thiosemicarbazones. Transition Metal Chemistry, 23: 355 - 356.

20. Agata, T. K. (2014). On the verification of binding modes of $p$-dimethylaminobenzaldehyde with mercury(II). The solid state studies. Journal of Molecular Structure, 1072: 284 - 290.

21. Bisceglie, F. Pinelli, S., Alinovi, R., Goldoni, M. and Mutti, A. (2014). Cinnamaldehyde and cuminaldehyde thiosemicarbazones and their copper(II) and nickel(II) complexes: A study to understand their biological activity. Journal of Inorganic Biochemistry, 140: 111 - 125.

22. Brindha, G. \& Vijayanthimala, R. (2015). Synthesis, characterization of novel Copper(II), nickel(II) complexes of $\mathrm{N}$-substituted thiosemicarbazides: Evaluation of anti-bacterial, anti-fungal and anti-cancer activities. Journal of Chemical and Pharmaceutical Research, 7(3): 225 - 231.

23. Silva, J. G. D., Wardell, S. M. S. V., Wardell, J. L. and Beraldo, H. (2009). Zinc(II) complexes of 2-pyridinederived N(4)-p-tolylthiosemicarbazones: Study of in vitro antibacterial activity. Journal of Coordination Chemistry, 62(9): 1400 - 1406.

24. Poyraz, M., Sari, M., Ney, A. G., Demirci, F., Demirayak, S. and Sahin, E. 2008. Synthesis, characterization and antimicrobial activity of a $\mathrm{Zn}(\mathrm{II})$ complex with 1-(1H-benzoimidazol-2-yl)-ethanone thiosemicarbazone. Journal of Coordination Chemistry, 61(20): 3276 - 3283.

25. El-Asmy, A. A., El-Gammal, O. A. and Saleh, H. S. (2008). Spectral, thermal, electrochemical and analytical studies on $\mathrm{Cd}(\mathrm{II})$ and $\mathrm{Hg}(\mathrm{II})$ thiosemicarbazone complexes. Spectrochimica Acta Part A, 71:39- 44.

26. Tulay, B-D., Musa, S., Esin, K., Mustafa, O., Bahri, U. and Resat, A. (2015). Synthesis and antioxidant activities of transition metal complexes based 3-hydroxysalicylaldehyde-S-methylthiosemicarbazone. Spectrochimica Acta Part A: Molecular and Biomolecular Spectroscopy, 138: 866 - 872.

27. Kenawy, I. M., Hassanien, M. M., Abdel-Rhman, M. H., Zaki, R. R. and Rashed, H. S. (2016). Synthesis and characterization of $\mathrm{Hg}(\mathrm{II})$ and $\mathrm{Cd}(\mathrm{II})$ complexes derived from the novel acenaphthaquinone-4-phenyl thiosemicarbazone and its CPE application. Egyptian Journal of Basic and Applied Sciences, 3(1): 106 - 117. 
28. Taha, Z. A., Ajlouni, A. A. M. and Momani, W. A. (2012). Structural, luminescence and biological studies of trivalent lanthanide complexes with $N, N^{\prime}$-Bis(2-Hydroxynaphthylmethylidene)-1,3-propanediamine Schiff base ligand. Journal of Luminescence, 132: $2832-2841$.

29. Stanojkovic, T. P., Kovala-Demertzi, D., Primikyri, A., Garcia-Santos, I., Castineiras, A., Juranic, Z. and Demertzis, M. A. (2010). Zinc(II) complexes of 2-acetyl pyridine 1-(4-fluorophenyl)piperazinylthiosemicarbazone: Synthesis, spectroscopic study and crystal structures - Potential anticancer drugs. Journal of Inorganic Biochemistry, 104: 467 - 476.

30. Waleed, M. A. M. (2013). A study of in vitro antibacterial activity of lanthanides complexes with a tetradentate Schiff base ligand. Asian Pacific Journal of Tropical Biomedicine, 3(5): 367 - 370.

31. Obaleye, J. A., Adediji, J. F. and Adebayo, M. A. (2011). Synthesis and biological activities on metal complexes of 2,5-diamino-1,3,4-thiadiazolederivedfrom semicarbazide hydrochloride. Molecules, 16(7): 5861 5874.

32. Sankaraperumal, A., Karthikeyan, J., Shetty, A. N. and Lakshmisundaram, R. (2013). Nickel(II) complex of $p$ [N.N-bis(2-chloroethyl)amino]benzaldehyde-4-methylthiosemicarbazone: Synthesis, structural characterization and biological application. Polyhedron, 50: $264-269$. 